http://dx.doi.org/10.11646/phytotaxa.162.1.5

\title{
Studies in the Neotropical Apocynaceae L: The genus Allamanda in Colombia and a new combination
}

\author{
J. FRANCISCO MORALES \\ Department of Plant Systematics, University of Bayreuth, Universitätsstr. 30, 95440 Bayreuth, Germany; email:
} drjfranciscomorales@gmail.com

\begin{abstract}
A brief synopsis of the genus Allamanda (Apocynaceae, Rauvolfioideae) in Colombia is presented, including a key, photographs of the species, and a new combination, A. salicifolia.
\end{abstract}

Key words: Gentianales, Plumerieae, Rauvolfioideae, South America

\section{Resumen}

Una breve sinopsis del género Allamanda (Apocynaceae, Rauvolfioideae) en Colombia se presenta, incluyendo una clave, fotografías de las especies y una nueva combinación, A. salicifolia.

\section{Introduction}

Allamanda Linnaeus (1771: 214) (Apocynaceae, Rauvolfioideae, Plumerieae) is a small genus mostly restricted to Brazil, with a few native species in Venezuela, Colombia, and Peru (Sakane \& Shepherd, 1986). The last monograph of the genus (Sakane $\&$ Shepherd, 1986) recognized thirteen species. An additional taxon, endemic to limestone outcrops in south western Bahia and northern Minas Gerais, Brazil, was recently published by SouzaSilva \& Rapini (2009), increasing the number of taxa to fourteen. Allamanda can be recognized by the following combination of characters: leaves verticillate, subverticillate, opposite or subopposite, infundibuliform corolla (usually slightly zygomorphic), with a corona of hairs within the tube and above the anthers, style-head with an annular ring at the base, dehiscent capsular fruits, commonly echinate on the external surface, and winged seeds (Morales, 2005). Only three species lack echinate fruits: A. laevis Markgraf (1940: 131), A. nobilis Moore (1868: 918), and A. weberbaueri Markgraf (1924: 77), but all share the rest of the morphological characters of the genus (Figs. 1-2). Allamanda has been used widely as an ornamental plant in the tropics, mainly for its showy flowers, flowering throughout the year, and easy vegetative propagation. Currently, only four species are used as ornamentals (A. cathartica Linnaeus (1771: 214), A. blanchetii Candolle (1844: 319), A. doniana Müller Argoviensis (1860: 11) (mostly in northern Brazil), and A. schottii Pohl (1827: 73) and many horticultural varieties are found among these.

Sakane and Shepherd (1986) reported two species for Colombia, A. nobilis T. Moore, based on a specimen collected in the Magdalena Valley (Haught 3700, COL, SP) and A. thevetiifolia Müller Argoviensis (1860: 388), known only from the type at that time. However, since the type locality (Maypures, Orinoco) of the latter species is actually in Venezuela (Amazonas state), the report for Colombia was erroneous. During the preparation of the treatment of Apocynaceae s.s. (subfamilies Apocynoideae and Rauvolfioideae) for the Flora of Colombia, almost all the type collections of taxa reported for that country have been studied, as well as specimens cited in different monographs, in order to confirm the identity of every species. A careful examination of Haugth 3700 reveals that it is a typical specimen of $A$. cathartica, with leaf blades somewhat pubescent. Therefore, A. nobilis should be considered restricted to northern Brazil and SE Venezuela. 


\section{Acknowledgements}

I thank the following herbaria for allow me to study their specimens B, BM, BR, B, CHOCO, COAH, COL, HUA, INB, JAUM, MA, MEDEL, MO, NY, P, S, US, VALLE. Julio Bentacur (COL), Ricardo Callejas (HUA), Dáyron Cárdenas (COAH), Felipe Cardona (HUA), and Álvaro Idárraga (HUA) helped in many ways, either supporting the field work or providing facilities for the study of herbarium material in Colombia. I acknowledge Michael Grayum (MO) for providing critical references and helpful commentaries concerning the Code of Botanical Nomenclature and Barry Hammel (MO) for the English revision on the manuscript. I would like to thank both reviewers for their insightful comments on the paper.

\section{References}

Candolle, A. (1844) Apocynaceae. In: Candolle, A. (ed.), Prodromus systematis naturalis regni vegetabilis Vol. 8. Paris, Treuttel \& Würtz, pp. 317-489 http://dx.doi.org/10.5962/bhl.title.286

Fielding, H.B. \& Gardner, C. (1844). Sertum Plantarum Vol 1(2). Bailliere, London, 25 pp.

Jarvis, C.E., Barrie, F.R., Allan, D.M. \& Reveal, J.L. (1993) A list of Linnaean generic names and their types. Regnum Vegetabile 127: 1-100. http://dx.doi.org/10.2307/1223568

Linnaeus, C.A. (1771) Mantissa Plantarum Altera Generum Editionis VI et Specierum Editionis II. Stockholm, Laurentii Salvii. $443 \mathrm{pp}$. http://dx.doi.org/10.5962/bhl.title.69083

Markgraf, F. (1924) Neue Apocynaceen aus Sudamerika. Notizblatt des Botanischen Gartens und Museums zu Berlin-Dahlem 8: $77-78$. http://dx.doi.org/10.2307/3994432

Markgraf, F. (1940) Nueu Apocynaceen aus Sudamerika 8. Notizblatt des Botanischen Gartens und Museums zu BerlinDahlem 15: 131-132. http://dx.doi.org/10.2307/3995102

Moore, T. (1868) New plants. The Gardeners' Chronicle \& Agricultural Gazette 180: 918.

Morales, J.F. (2005) Estudios en las Apocynaceae neotropicales XIX: La familia Apocynaceae s. str. (Apocynoideae, Rauvolfioideae) de Costa Rica. Darwiniana 43: 90-191.

Müller Argoviensis, J. (1860) Apocynaceae. In: Martius, C.F.P. (ed.), Flora brasiliensis 6(1). München, Wien, Leipzig, pp. 1180.

Pohl, J.E. (1827) Plantarum Brasiliae icones ed descriptiones hactenus ineditae. Vol. 1(3). Vienna, Antonii Strauss, 135 pp. http://dx.doi.org/10.5962/bhl.title.451

Roemer, J.J. \& Schultes, J.A. (1819) Caroli a Linné Systema vegetabilium: secundum classes, ordines, genera, species. Cum characteribus differentiis et synonymis. Editio nova, speciebus inde ab editione XV. Detectis aucta et locupletata. Vol. 4 Stuttgart, $888 \mathrm{pp}$.

Sakane, M. \& Shepherd, G.J. (1986) Uma revisão do gênero Allamanda L. (Apocynaceae). Revista Brasileira de Botanica 9: $125-149$.

Siebert, A. \& Voss, A. (1894) Vilmorin's Blumengärtnerei Beschreibung, Kultur und Verwendung des gesamten Pflanzenmaterials für deutsche Gärten. Ed. 3. Vol. 1 Berlin, Paul Parey, 832 pp. http://dx.doi.org/10.5962/bhl.title.67392

Souza-Silva, R.F. \& Rapini, A. (2009) Allamanda calcicola (Apocynaceae), an overlooked new species from limestone outcrops in the States of Minas Gerais and Bahia, Brazil. Kew Bulletin 64: 171-174. http://dx.doi.org/10.1007/s12225-008-9087-x

Woodson, R.E. (1936) Studies in the Apocynaceae IV. The American genera of Echitoideae [concl.]. Annals of the Missouri Botanical Garden 23: 169-438. http://dx.doi.org/10.2307/2394193 